Louisiana State University

LSU Digital Commons

Faculty Publications

Department of Biological Sciences

$5-1-2006$

\title{
Natural disturbances and the physiognomy of pine savannas: A phenomenological model
}

Frank S. Gilliam

Marshall University

William J. Platt

Louisiana State University

Robert K. Peet

The University of North Carolina at Chapel Hill

Follow this and additional works at: https://digitalcommons.Isu.edu/biosci_pubs

\section{Recommended Citation}

Gilliam, F., Platt, W., \& Peet, R. (2006). Natural disturbances and the physiognomy of pine savannas: A phenomenological model. Applied Vegetation Science, 9 (1), 83-96. https://doi.org/10.1658/ 1402-2001(2006)9[83:NDATPO]2.0.CO;2

This Conference Proceeding is brought to you for free and open access by the Department of Biological Sciences at LSU Digital Commons. It has been accepted for inclusion in Faculty Publications by an authorized administrator of LSU Digital Commons. For more information, please contact ir@lsu.edu. 


\section{Marshall University}

Marshall Digital Scholar

Biological Sciences Faculty Research

Biological Sciences

$5-2006$

\section{Natural disturbances and the physiognomy of pine savannas : A phenomenological model}

Frank S. Gilliam

Marshall University, gilliam@marshall.edu

William J. Platt

Robert K. Peet

Follow this and additional works at: http://mds.marshall.edu/bio_sciences_faculty

Part of the Forest Biology Commons, and the Other Ecology and Evolutionary Biology Commons

\section{Recommended Citation}

Gilliam FS, WJ Platt, and RK Peet. 2006. Natural disturbances and the physiognomy of pine savannas: a phenomenological model. Applied Vegetation Science 9:83-96.

This Article is brought to you for free and open access by the Biological Sciences at Marshall Digital Scholar. It has been accepted for inclusion in Biological Sciences Faculty Research by an authorized administrator of Marshall Digital Scholar. For more information, please contact zhangj@marshall.edu, martj@marshall.edu. 


\title{
Natural disturbances and the physiognomy of pine savannas: A phenomenological model
}

\author{
Gilliam, Frank S. ${ }^{*}$; Platt, William J. ${ }^{2} \&$ Peet, Robert K. ${ }^{3}$ \\ ${ }^{1}$ Department of Biological Sciences, Marshall University, Huntington, WV 25755-2510, USA; \\ ${ }^{2}$ Department of Biological Sciences, Louisiana State University, Baton Rouge, LA 70803-0100, USA; \\ ${ }^{3}$ Department of Biology, University of North Carolina, Chapel Hill, NC 27599-3280, USA; \\ *Corresponding author; Fax +1 3046963243; E-mail gilliam@marshall.edu
}

\begin{abstract}
.
Question: The decline of the Pinus palustris ecosystems has resulted from anthropogenic influences, such as conversion to pine plantation forestry, agriculture and land development, all of which are closely related to increases in human populations. Other effects, however, have arisen from alterations in disturbance regimes that maintain the structure and function of these ecosystems. How have alterations of the disturbance regime altered the physiognomy of 'old-growth' stands, and what are the implications for ecosystem conservation and restoration? Methods: In contrast to models that emphasize close interactions among the vertically complex strata, we develop a conceptual phenomenological model for the physiognomic structure of Pinus palustris stands. We relate two natural disturbances (tropical storms and fire) that affect different stages of the life cycle to different aspects of the physiognomic structure. We then compare overstorey stand structure and ground cover composition of two old-growth longleaf stands near the extremes of different composite disturbance regimes: the Wade Tract (frequent hurricanes and fire) and the Boyd Tract (infrequent hurricanes and long-term fire exclusion).

Results: We predict that tropical storms and fires have different effects on stand physiognomy. Tropical storms are periodic, and sometimes intense, whereas fires are more frequent and less intense. Hurricanes directly influence the overstorey via windcaused damage and mortality, and indirectly influence the herb layer by altering the spatial distribution of shading and litter accumulation. Fire exerts direct effects on juvenile stages and indirect effects on the herb layer via fine fuel consumption and selective mortality of potential competitors of $P$. palustris juveniles. These differences in effects of disturbances can result in widely different physiognomies for $P$. palustris stands. Finally, some global climate change scenarios have suggested that changes may occur in tropical storm and fire regimes, altering frequency and severity. Such changes may greatly affect pine stands, and ultimately entire pine savanna ecosystems.

Conclusions: Our phenomenological model of disturbance regimes in Pinus palustris old-growth produces very different physiognomies for different disturbances regimes that reflect natural process and human management actions. This model can be used to derive restoration strategies for pine savannas that are linked to reinstitution of important ecological processes rather than specific physiognomic states.
\end{abstract}

\section{Introduction}

Ecological restoration is focused on modifying degraded ecosystems (Noss et al. 2006) to improve their 'ecological integrity'. 'Natural' and/or 'historic' conditions can serve as a target for ecological restoration (Noel et al. 1998; Moore et al. 1999). For example, McCarthy (2003) suggested that old-growth deciduous forest stands should be used as benchmarks for restoration of highly-disturbed forests in eastern North America, and Gilliam \& Roberts (2003b) called for preservation of old-growth forests for such purposes. Such an approach is problematic when applied to systems in which the natural variation in old-growth conditions no longer exists (Schwartz 1994). Old-growth pine savannas typical of the original landscape of large areas of the southeastern USA are essentially gone; the few old-growth stands that remain represent a biased target in that nearly all occur on unusual site conditions. Moreover, these few remaining old-growth pine savannas often have been greatly altered by personal management decisions or from fire suppression (e.g. Gilliam \& Platt 1999).

We develop a different approach to establishing goals for restoration. Our prior studies have investigated the stand dynamics of old-growth pine savannas and the role of natural disturbances in stand dynamics (Walker \& Peet 1984; Platt et al. 1988; Platt \& Schwartz 1990; Platt \& Rathbun 1993; Doren et al. 1993; Gilliam et al. 1993; Noel et al. 1998; Platt 1999; Gilliam \& Platt 1999; Platt et al. 2000). In this paper we use this prior work to develop a conceptual, phenomenological, patch dynamics model that characterizes the dynamics of overstorey regeneration and patch dynamics within stands. We

Keywords: Boyd Tract; Fire ecology; Hurricane ecology; Longleaf pine; Old-growth forest; Pinus palustris ecosystem; U.S. Coastal Plain; Regeneration; Wade Tract.

Nomenclature: Anon. (2006). 
next examine how natural disturbances (hurricanes, fires) influence patch dynamics and regeneration, predicting differences in physiognomic characteristics of pine stands as a result of differences in natural disturbances. We then apply this model to two old-growth pine savannas with different ecological histories, the Wade Tract in southern Georgia and the Boyd Tract in the North Carolina Sandhills, to show that the same phenomenological model can produce very different physiognomies. Using the same two old-growth savannas, we then project how these stand physiognomies are likely to have been molded by natural processes and different human management actions. In this way, we use our model to derive strategies for restoration of pine savannas that are linked to reinstitution of important ecological processes rather than specific physiognomic states.

\section{A phenomenological model of pine savanna physi- ognomy}

Physiognomic structure is similar among different pine savanna ecosystems. Historically, these ecosystems covered large expanses with two layers of aboveground vegetation: overstorey trees and a ground cover of predominantly herbaceous vegetation. Even though there probably were inclusions of different types of vegetation (e.g. Harcombe et al. 1993; Platt et al. in press), the background matrix for most southeastern coastal plain uplands appeared to be overstorey pines and a ground cover layer (also see Frost 1993; Schwartz 1994; Peet 2006). Historical records (see Platt 1999 and references therein) and photographs (e.g. Schwarz 1907; Wahlenberg 1946; Gilliam \& Platt 2006) are consistent in documenting this two-layered physiognomy. This overstorey/ground cover physiognomic structure is independent of species composition and densities of dominant species, which vary geographically and often within sites (e.g. Noel et al. 1998). Different species of pines (e.g. P. palustris, $P$. elliottii var. densa, $P$. echinata, $P$. serotina) are present in pine savanna vegetation in different habitats in the different biogeographic regions across the southeastern United States (Platt 1999). The ground cover is generally dominated by large, warm-season $\left(\mathrm{C}_{4}\right)$ grasses, but species composition changes along moisture gradients within a site, as well as among biogeographic regions (e.g. Peet \& Allard 1993; Peet 2006). Thus, generation and maintenance of this physiognomy should be an important goal for ecological restoration and management of pine savannas.

A two-layered physiognomy involves cycling of overstorey species through the ground cover and into the canopy. We use demographic characteristics of pines and ground cover to develop a phenomenological patch- dynamics model that, as we propose, operates in all pine savannas. The demographic characteristics were used to generate four 'rules' that relate patch dynamics to the formation of a two-layered physiognomy. These rules generate a cycle shown in Figs. 1 - 3. At this point, we do not consider environmental processes that might drive the system. For convenience, we start with the entrance of pines into the ecosystem as seeds, following the life cycle until pines enter the overstorey.

Savanna pines commonly mast, producing large seed crops at periodic intervals. For example, cone-bearing longleaf pines, especially in old-growth stands, mast at irregular intervals. As many as $400-800$ cones may be produced by large, overstorey trees (W.J. Platt unpubl. data). Dispersal via wind occurs over distances as large as $200 \mathrm{~m}$ (Grace et al. 2004). Thus, in mast years, first seeds and then seedlings of savanna pines tend to be widely distributed in the vicinity of large trees (Grace \& Platt 1995a, b; Platt 1999, Grace et al. 2004). Consequently, juvenile pines are expected in areas with and without overstorey pines, as long as there are sufficient cone-producing trees in the vicinity. We note that there are many reasons why there might not be abundant pines in savanna landscapes, but that dispersal limitation is not likely the cause when there are sufficient large adult trees for seeds to reach areas without such trees.

Rule 1: Seeds and seedlings should occur throughout all patches within dispersal range of large trees, both patches with and without overstorey trees.

The juvenile stages of savanna pines (particularly $P$. palustris and $P$. elliottii var. densa) may persist in the ground cover for several to many years (Wahlenberg 1946; Landers 1991). While in the ground cover, juvenile pines are negatively influenced by any overstorey trees in the vicinity (Platt \& Rathbun 1993; Grace \& Platt 1995a, b). Recruitment into the overstorey thus is confined to openings in the overstorey (Platt et al. 1988; Platt \& Rathbun 1993; Grace \& Platt 1995a, b; Palik et al. 1997; Brockway \& Outcalt 1998; McGuire et al. 2001). The size of opening needed for recruitment is expected to vary with local site conditions such as soil types and moisture, the density of vegetation (and hence competition), as well as fuel loading by pines and the ground cover.

Rule 2: Growth out of the ground cover and thus recruitment into the overstorey only occur in patches that do not contain overstorey trees.

Vegetation in the ground cover of pine savannas can be separated into two layers that contain similar growth forms corresponding to small-and large-stature plants 
(Figs. 1 - 3) (Platt et al. 2006). Guilds have been distinguished by Gilliam \& Roberts (2003a) on the basis of whether the focal plants remain in the small-stature layer throughout their life cycle (resident species) or potentially leave the small-stature layer to become largestature ground cover plants (transient species). The forbs and graminoids of the small-stature layer contribute most of the biodiversity in the pine savanna ecosystem and largely remain as resident species of that layer. Transient species in the ground cover include large warm-season $\left(\mathrm{C}_{4}\right)$ grasses, large forbs, shrubs and lianas, as well as juvenile pines. Interactions in the ground cover are presumed to be governed by the assembly rule that larger plants exert strong and unidirectional depressant effects on smaller plants (Weiher \& Keddy 1999). Thus, species composition and structure of the ground cover in pine savannas vary with the spatial and temporal coincidence of the resident and transient plant groups.

Juvenile pines are prominent transient species in the ground cover. The juveniles typically are present in the small-stature layer of the ground cover for a number of years (Wahlenberg 1946). Initially, growth and survival are influenced by large-stature species of the ground cover. The likelihood of survival, rates of growth, and the duration of susceptibility to suppression in the ground cover depend primarily on competitive interactions determined largely by the presence and biomass of largestature plants.

Once in the large-stature layer of the ground cover, juvenile pines become part of the large-stature guild that exerts depressant effects on smaller-stature plants. The initial juveniles reaching large stature suppress smaller pines, creating a size-structure driven competitive hierarchy among the juveniles in a patch of recruits.

Rule 3: Although juvenile pines enter the ground cover as small-stature species subject to depressant effects exerted by large-stature species of the ground cover, once in the large-stature layer they are no longer subject to ground cover assembly processes.

Once pines emerge from the ground cover, overstorey patch dynamics become important. Pines make the transition from ground cover to overstorey in a few years (Rebertus et al. 1993), and thus they become part of patches influenced by interactions among recruits now in tree stages, and especially larger trees in the vicinity (Platt and Rathbun 1993). Patches of small trees within stands grow and thin over time periods of up to many decades, gradually merging newer patches of trees into a more random background pattern of larger trees of uneven age and size (Platt et al. 1988; Platt \& Rathbun 1993; Grace \& Platt 1995a, b; Noel et al. 1998). Over time, slow death of overstorey trees, primarily from lightning strikes and windthrows, opens new canopy patches with a treeless state and of a size suitable for recruitment (Platt et al. 1988).

Rule 4: Density and size-dependent interactions among pines in patches govern patch dynamics, with largely independent stochastic mortality removing individual canopy trees and generating new treeless patches over time.

The overstories of well-studied, old-growth pine stands typically consist of patches or local cohorts of trees. Within patches trees were recruited within a few years of each other, but among patch recruitment times vary over many decades and often centuries (Platt et al. 1988; Platt \& Rathbun 1993; Doren et al. 1993; Platt et al. 2000). These local patch dynamics determine overstorey structure in pine savannas. Moreover, the dynamics of any single overstorey patch appear independent of surrounding patches (Platt \& Rathbun 1993). Internal patch rules govern the numbers and sizes of trees present, as well as rates of opening of new patches and rates of change in existing patches. As these rules are not specified by our phenomenological model, a wide range of overstorey stand structures is possible within patches in old-growth stands, from scattered large trees to high densities of small stems to intermediate densities with mixed stems sizes (Noel et al. 1998).

This four-rule, phenomenological model generates physiognomic structure of pine savannas as a two-state system. This model also generates a two-stage patch model: those with overstorey and ground cover and those with only ground cover (including juvenile pines, if present). Variation over space and time in the significance of the four rules can influence physiognomic structure within and among stands.

\section{Incorporating natural disturbances as drivers in the phenomenological model}

We propose that the physiognomy of southeastern pine savannas is influenced by two large-scale disturbances, fires and hurricanes. These affect different lifecycle stages of Pinus palustris. Hurricanes affect primarily overstorey trees, whereas fires affect primarily juvenile stages in the ground cover. It is likely, therefore, that these disturbances will affect different aspects of patch dynamics, and ultimately the physiognomy of pine savannas.

Over the past century, tropical storms typically have crossed any given site on the southeastern US coastal plain once every few decades, usually toward the end of the summer wet season (Simpson \& Lawrence 1971; 
Conner et al. 1989). Most tropical storms have been of low intensity, with high intensity storms occurring every few centuries (Batista \& Platt 1997). Tropical storms have been hypothesized to have differential effects on species and sizes of trees in forests (Quigley \& Platt 2003). Several hurricanes of the past 20 years (e.g. Kate 1985; Joan 1988; Hugo 1989; Andrew 1992; Fran 1996) have stimulated study of forest trees, particularly the effects on mortality and recruitment and consequent population dynamics (see papers in Walker et al. 1991; Gresham et al. 1991; Stone \& Finkl 1995; Platt et al. 2000, 2002; Batista \& Platt 2003). Most studies have been conducted in subtropical and warm temperate hardwood forests where mortality of trees has been typically $<20 \%$ and where resprouting has been extensive. These studies have postulated different effects and responses (Batista \& Platt 2003). Emergent concepts relate variations in wind damage and responses of species to variations in direct regeneration of forest structure after a tropical storm.

Tropical storms influence overstorey stages of pine populations. The primary effects include damage and mortality of established, large trees, changing Rule 4 by opening multiple patches synchronously (Fig. 1). As a result, there is potential for synchronized recruitment that might produce large cohorts of similar age, but located in different and perhaps large patches (Rule 1). Inside patches in which the trees are severely damaged or killed, two things may occur. Increased light in areas without deposited biomass should facilitate recruitment of pines (Rule 2). In addition, the rapid opening of patches may stimulate growth of any recruits present prior to responses by the herbaceous ground cover (Rule 3). Nonetheless, litterfall occurs in many patches, either with intact or opened overstorey. Where present, this deposited litter should locally suppress both recruitment and growth/survival of any recruits present at the time of the hurricane (Rules 1-3). Furthermore, when the largest trees are heavily damaged, as in moderate-major hurricanes (Platt \& Rathbun 1993; Platt et al. 2000), there may be a reduction in cone/seed production that greatly reduces the likelihood of colonization of open patches for a number of years, generating time lags in regeneration (Rule 1). Thus, hurricanes are predicted to affect all four rules, but in different ways depending on local hurricane-generated changes. Spatial variation in effects on these rules should produce spatial variation in effects on stand physiognomy. Thus, hurricanes should generate local variation in patch dynamics, producing differences in stand physiognomy across the landscape.

Historically, natural fires that burned large areas were frequent in pine savannas. Ignition most often resulted from lightning produced by thunderstorms during the transition from dry springs to wet summers

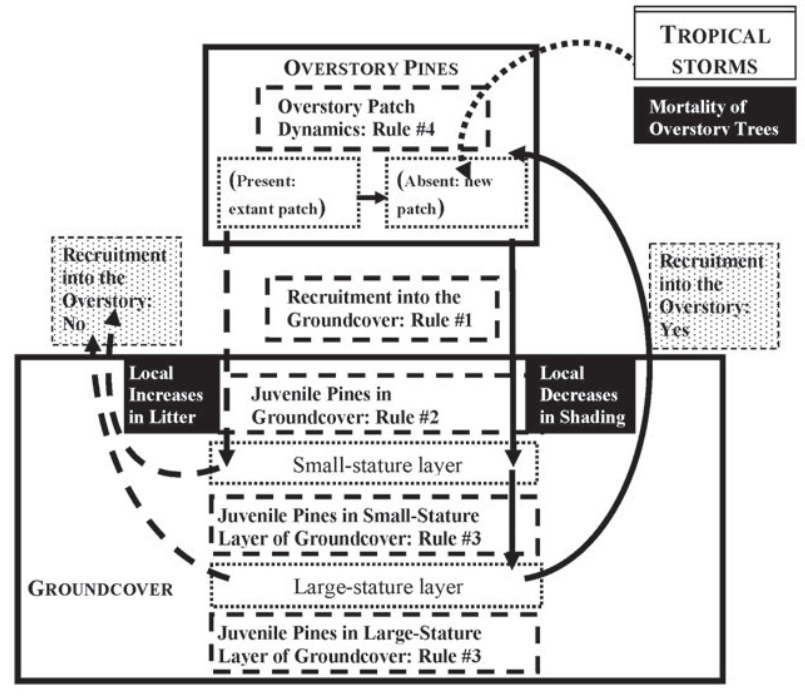

Fig. 1. Predicted effects of tropical storms on the patch dynamics of savanna pines. Tropical storms increase mortality of large trees, increasing numbers and sizes of open patches, thus potentially enhancing recruitment into the ground cover and the overstorey. Local increases in litter and responses of the ground cover to opening of the overstorey may depress recruitment of pines, causing lags in recruitment into open patches. Solid and dashed arrows denote positive and negative effects, respectively, on recruitment into the overstorey.

(Olson \& Platt 1995; Platt 1999; Slocum et al. 2003). Fire spread across the landscape was influenced by a combination of weather and fuels. Fire spread across landscapes has been hypothesized to result, in large part, from pyrogenic fine fuels in the ground cover (e.g., live and standing senescent warm-season grasses) and litter that does not decompose rapidly over the infertile soils of the region (Williamson \& Black 1981; Gilliam 1991; Platt et al. 1991; Olson \& Platt 1995). Rapid drying of fine fuels potentially provided connectivity of flammable fuels across large areas in the spring, especially during La Niña episodes (Beckage et al. 2003). Return intervals of 1-3 a have often been reported (Frost 1998), based on high frequencies of lightning strikes (e.g. Hodanish et al. 1997). Even on small barrier islands during periods with little human presence, fires occurred on average every 4 a, primarily during the transition from dry springs to wet summers. These frequent fires were typically of relatively low intensity because high frequency would keep fine fuel loads low (Platt 1999, but see Thaxton 2003; Thaxton \& Platt in press; Drewa et al. 2006). These fires have been hypothesized to produce open woodland/savanna with two physiognomic layers by exerting strong depressant effects on hardwood trees that form a dense, mid-storey layer and 


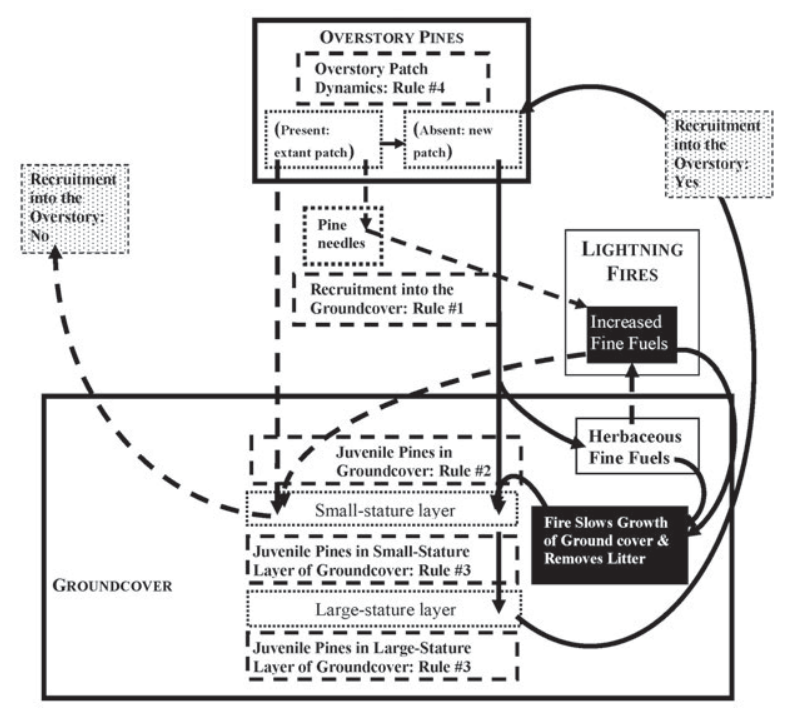

Fig. 2. Predicted effects of natural lightning fires on the patch dynamics of savanna pines. In patches with trees, the high densities of needles increase the intensity of fires, which kills juvenile pines in the ground cover and thus depresses recruitment of pines. In open patches, increased growth of ground cover generates increased fine fuels, but without high densities of pine needles. Fires transiently slow regrowth of ground cover and remove litter, potentially enhancing recruitment into the ground cover and the overstorey more than expected only on the basis of open patches. Solid and dashed arrows denote positive and negative effects, respectively, on recruitment into the overstorey.

suppress the ground cover in the absence of such fires (Platt et al. 1988, 1991; Streng et al. 1993; Glitzenstein et al. 1995; Drewa et al. 2002).

Frequent fires are widely recognized to influence growth and survival of pines in the earliest life cycle stages. Even low-intensity, dormant-season fires kill almost all seedlings (<1 a old) (Hermann 1993). Pregrass-stage juveniles also experience substantial mortality during growing-season fires (Grace \& Platt 1995a, b). These early life-cycle stages are particularly vulnerable to fires under pines (Grace \& Platt 1995a, b), where pyrogenic needles elevate fire intensity (Thaxton $\&$ Platt in press). In contrast, once juveniles are in the grass stage they experience low mortality during fires, and growth may actually increase after growing season fires. Mortality risk may be elevated somewhat during the transition from grass stage to tree stages, especially at longer fire-return intervals (Rebertus et al. 1993), but is very low for large trees in frequently burned savannas. Repeated fires should affect pines in patches without overstorey trees, especially pine seedlings and pre-grass stage juveniles in those patches. Consequently, frequent, even low-intensity fires can influence likelihoods

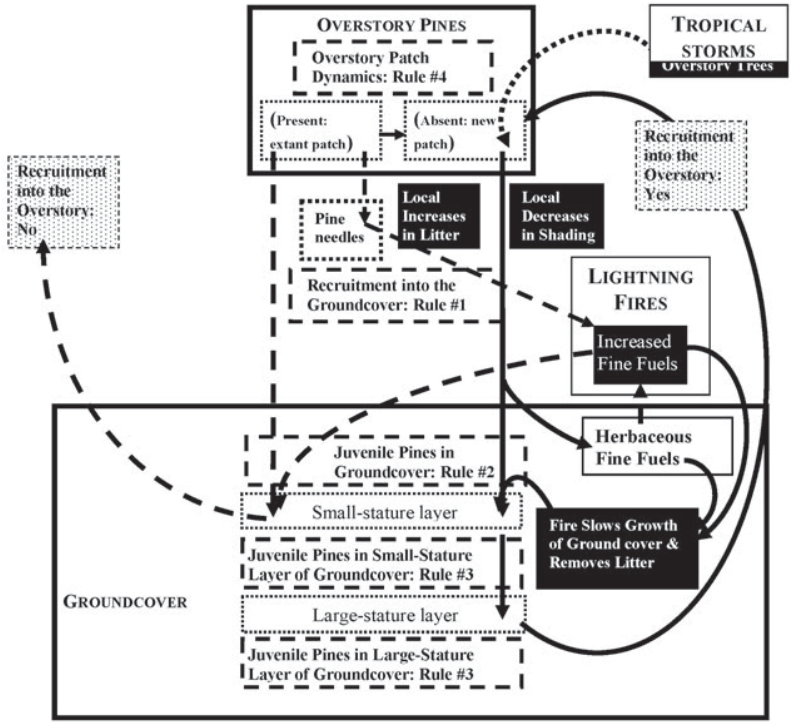

Fig. 3. Combined effects of tropical storms and fires on patch dynamics of savanna pines. Because the two disturbances directly affect different life cycle stages, interactive effects should be expected to be mediated through effects of hurricanes on subsequent fires rather than directly on pines. Solid and dashed arrows denote positive and negative effects, respectively, on recruitment into the overstorey.

of transition from a treeless to a treed state, and thus the openness of the overstorey layer.

Fires influence juvenile stages that potentially generate new overstorey in patches, but have different effects on different juvenile stages (Fig. 2). Fires alter Rule 3, influencing mortality of pines in the smallstature layer. Mortality of juveniles should be increased in areas with an overstorey because high densities of pine needles result in more intense fires and juveniles are stressed by interactions with large trees (Platt \& Rathbun 1993; Grace \& Platt 1995a, b). Such mortality should slow formation of new patches of overstorey trees because a lag time occurs between opening of patches and colonization, lengthening the patch cycle. Fires also transiently reduce herbaceous cover and litter (Platt et al. 1999 and references therein) and suppress most woody species of shrubs and trees (Glitzenstein et al. 1995; Drewa et al. 2002, 2006; Thaxton \& Platt in press). As a result, recruitment, growth, and survival of pines in patches without trees should increase with fire frequency up to a frequency of approximately two years, where upon Rule 1 is modified, even though the herbaceous ground cover when fully recovered may slow 
growth of pines. Moreover, the effects should vary with the patchiness and variation in characteristics of fires. Fires in the winter/dry season should burn somewhat uniformly across the landscape. In contrast, fires become progressively patchier and less intense as the lightning season progresses (Slocum et al. 2003), resulting in low intensity or unburned patches. Such variation is likely to produce differential fire effects across pine savanna landscapes burned by frequent lightning-season fires.

Hurricanes and fires potentially have interactive effects. The damage and mortality of overstorey trees involves transfer of biomass from the overstorey to the ground cover, locally increasing both coarse and fine fuels (Fig. 3). Once dry, these additional fuels (pine needles, wood) burn at increased intensity in the subsequent fire (Platt et al. 2002; Thaxton 2003; Thaxton $\&$ Platt in press). Thus, hurricane-generated fuels can potentially affect both large- and small-stature components of the ground cover, opening gaps through increased intensity created by the added fuels and thereby increasing pine seedling recruitment, but also generating reduced intensity of subsequent fires when litter influx from the pines is reduced (Platt et al. 2002). Thus the interactive effects of hurricanes and fires depend on the context of prior regeneration by overstorey pines. If juveniles are present in the ground cover, increased fire intensity is likely to cause elevated mortality in local patches with increased biomass. Regardless of the presence of juveniles, the effects of increased fire intensity on the ground cover are likely to include increased establishment, more rapid growth, and higher survival of pines recruited after the fire. These interactive effects should increase the variation in both within and among stand physiognomy.

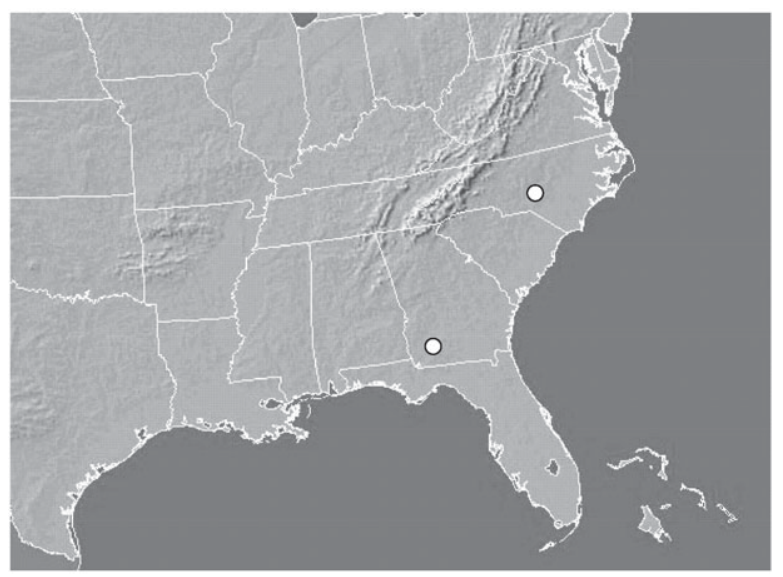

Fig. 4. Map of the southeastern United States showing the locations of the two old-growth study sites used in this study: Wade Tract in Georgia and Boyd Tract in North Carolina.

\section{Application of the phenomenological model to old- growth stands.}

To illustrate and validate our conceptual, heuristic model of pine savanna dynamics, we examine two wellstudied, old-growth Pinus palustris stands, the Wade Tract of southern Georgia and the Boyd Tract of the Sandhills of North Carolina. Our purpose is to relate the observed and contrasting overstorey structure and ground cover composition at these sites to the phenomenological model. It should be noted that these on-going studies were conceived and are carried out independent of one another. Thus, they employ different designs, sampling, and analyses. However, use of statistical methods appropriate to the respective designs allows us to address the predictions of the model simultaneously.

\section{Sites}

The Wade Tract, ca. 80 ha of the Arcadia Plantation in the Tallahassee Red Hills region (Thomas County) of southern Georgia $\left(30.8^{\circ} \mathrm{N}, 84^{\circ} \mathrm{W}\right.$; Fig. 4), is located 100 $\mathrm{km}$ from the Gulf of Mexico. Soil parent materials for this region are generally Cretaceous unconsolidated sand and clay layers uplifted during the late OligoceneMiocene (Platt \& Schwartz 1990). Surficial soils are predominantly silty, fine-textured sands with A horizons 50-100 cm thick, uniform, and acidic. The rolling topography of the Wade Tract is generally $120-130 \mathrm{~m}$ above mean sea level, with the moister, lower-elevation site types being less frequent. There are no records that indicate logging of living trees on the Wade Tract (Platt et al. 1988). Arcadia Plantation, including the Wade Tract, has been burned biennially (occasionally annually, and rarely at longer intervals) for as long as plantation records exist, mostly in the late winter. Since 1983, the site has been managed by Tall Timbers Research Station using biennial fires. About half the prescribed fires have occurred in the transition from dry springs to wet summers.

The Boyd Round Timber Natural Area (Boyd Tract) occupies approximately 66 ha of the Fall-line Sandhills physiographic region of south-central North Carolina $\left(35.2^{\circ} \mathrm{N}, 79^{\circ} \mathrm{W}\right.$; Fig. 4). Elevation ranges from 137 to $186 \mathrm{~m}$ above mean sea level. Parent materials for much of this area of the state (Moore County) are primarily unconsolidated sand and clay layers deposited in the Cretaceous. There are two distinct site types of approximately equal area at the Boyd Tract that differ in elevation, soil texture, and dominant vegetation. Upland sites are underlain by clay with surficial loamy sand soils ( $25 \%$ silt); lowland sites have coarse-textured sands (Gilliam et al. 1993). The history of the Boyd Tract prior to its purchase by the Boyd family at the turn of the 20th 
century is not well known. The presence of several stems older than 400 a indicates that the site has contained Pinus palustris at least since the mid-1500s (Gilliam et al. 1993). The Boyd Tract burned in 1909, the result of a wildfire throughout much of the area. The fire history prior to this event is unclear, but no other fires occurred between 1909 and initiation of this study in 1989 .

\section{Sampling methods}

Sampling methods differed at the two sites. Data on Wade Tract trees were obtained from the original sampling of a 40-ha mapped plot established in 1979 (see Platt et al. 1988), which involved mapping of all pines $>$ $1.5 \mathrm{~m}$ tall and all hardwoods $\geq 2 \mathrm{~cm} \mathrm{DBH}$. Species and diameter at $1.5 \mathrm{~m}$ (hereafter, $\mathrm{DBH}$ ) also were recorded. Data for the Boyd Tract trees were obtained in 1989, using 60 circular 0.04-ha sample plots, 30 each located randomly in upland and lowland areas. All stems $\geq 2.5$ $\mathrm{cm} \mathrm{DBH}$ within each plot were identified and $\mathrm{DBH}$ recorded.

Data used for comparisons was standardized. For the Wade Tract, total basal area and densities of all tree species were calculated based on data within the entire 40 ha plot. Relative basal area and density are expressed as percentages of totals within the plot. For the Boyd Tract, total and relative measures of basal area and densities of all tree species were calculated from the pooled 60 samples. Measurements at both sites were expressed as basal area or density per ha.

Analyses of spatial pattern (i.e., degree of patchiness) of Pinus palustris differed between sites. For the Wade Tract, we used the spatial patterns characterized by Noel et al. (1998) based on stand maps using the 1978 census. For the Boyd Tract, we used Poisson analysis to determine random versus non-random dispersion. Pattern was assessed by comparing differences between observed and expected values based on the Poisson distribution (Zar 1996).

Ground cover species composition and relative abundance were sampled at both sites. Species numbers were recorded within $20-\mathrm{m} \times 50$-m plots at both sites using methods developed by the Carolina Vegetation Survey (CVS; Peet et al. 1998). Relative abundances were estimated as the averages of cover classes estimated within four intensively sampled $10-\mathrm{m} \times 10$-m modules within each plot, using the CVS cover class criteria:

$1=$ trace $; 2=0-1 \% ; 3=1-2 \% ; 4=2-5 \% ; 5=5-10 \% ; 6=$ $10-25 \% ; 7=25-50 \% ; 8=50-75 \% ; 9=75-95 \% ; 10=>95 \%$.

Data reported here include two plots each in upland and lowland sites at the Boyd Tract and three plots sampled at the Wade Tract, one in the uplands, one on the slopes, and one in bottomland flatwoods.

\section{Overstorey comparisons}

Structural characteristics contrasted sharply between Pinus palustris stands on the Boyd and Wade Tracts. Whereas basal area of $P$. palustris was $>96 \%$ of the total at the Wade Tract, it was just over $50 \%$ at the Boyd Tract (Fig. 5a). Furthermore, although relative basal area of $P$.palustris was much lower at the Boyd Tract, absolute basal area of $P$. palustris was more than twice that at the Wade Tract (Fig. 5a). Stand differences in relative density of $P$. palustris were even more striking than those for relative basal area, $77 \%$ for the Wade Tract versus 9\% for the Boyd Tract, respectively (Fig. 5b). The absolute density of $P$. palustris was, however, only slightly greater $(15 \%)$ at the Wade Tract than at the Boyd Tract (Fig. 5b).

These differences in basal area and density of Pinus palustris at the two sites reflected differences in ageclass frequency distributions (Fig. 6). Almost half (45\%) of $P$. palustris stems were $0-25$ a at the Wade Tract, but $<10 \%$ were in this age class at the Boyd Tract. Indeed, the age class with highest frequency at the Boyd Tract was 75-100 a.

There were also notable contrasts between sites in the frequencies of old (e.g. $>100$ a) Pinus palustris. Whereas $<17 \%$ of $P$. palustris stems at the Wade Tract
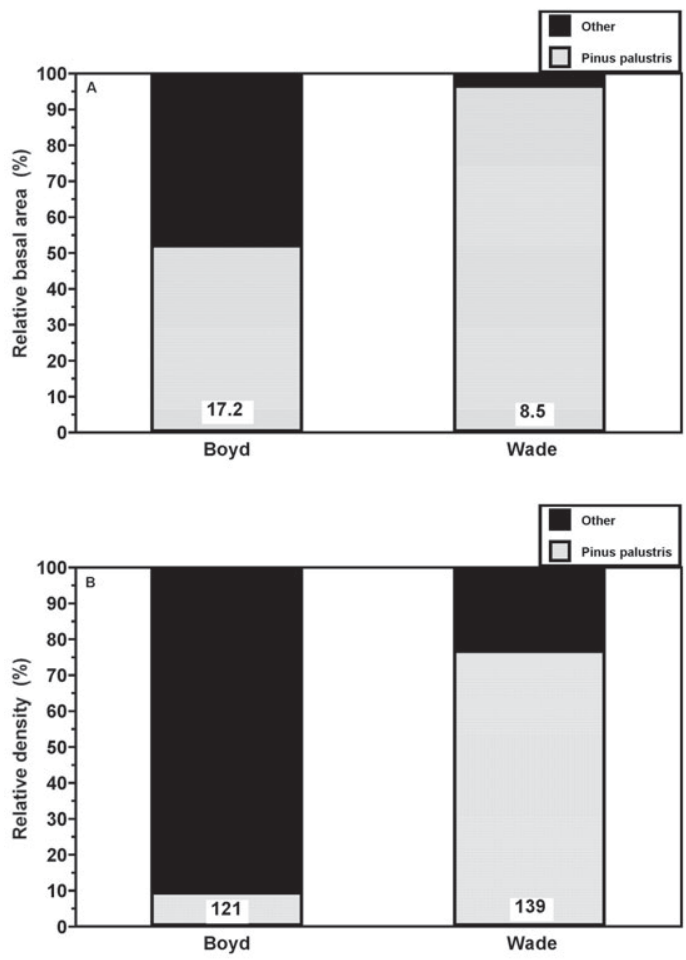

Fig. 5. A. Relative basal area; B. Relative density of stems of Pinus palustris $(\geq 2.5 \mathrm{~cm} \mathrm{DBH})$ at the Wade and Boyd Tracts. Numbers shown are absolute measures of average basal area $\left(\mathrm{m}^{2} /\right.$ ha) and density (stems/ha) of P. palustris. 
were $>100$ a old, ca. $40 \%$ of stems at the Boyd Tract were $>100 \mathrm{a}$. This contrast was particularly pronounced for stems between 100 and 200 a old. Greater than onethird of all stems at the Boyd Tract were within this range, but only about $10 \%$ were in this range at the Wade Tract (Fig. 6). Thus, overall greater basal area of $P$.palustris at the Boyd Tract resulted from much higher density and likely higher survival of older trees.

Old pines are more uniformly distributed on the Boyd Tract than the Wade tract. We assessed dispersion of $P$. palustris at the Boyd Tract using Poisson analysis and rejected the hypothesis that $P$. palustris is randomly distributed (Zar 1996; statistical results are presented in Table 1; $\chi^{2}$ was 42.5 , greater than the tabular $\chi^{2}$ of 18.31 , with $\alpha=0.05$ and $d f=10$ ). The greatest departure from the expected frequencies occurred for plots with 0-2 stems per plot (i.e. there were far more plots with just one $P$. palustris stem than would have been expected if this pattern were random). On the other hand, there also were more plots with $\geq 8$ stems per plot than expected. The paucity of plots with intermediate frequencies of trees suggests a period with little recruitment. Further examination of plots reveals spatial differences in patterns of recruitment. Fig. 7 presents relative size-class distributions for $P$. palustris stems in
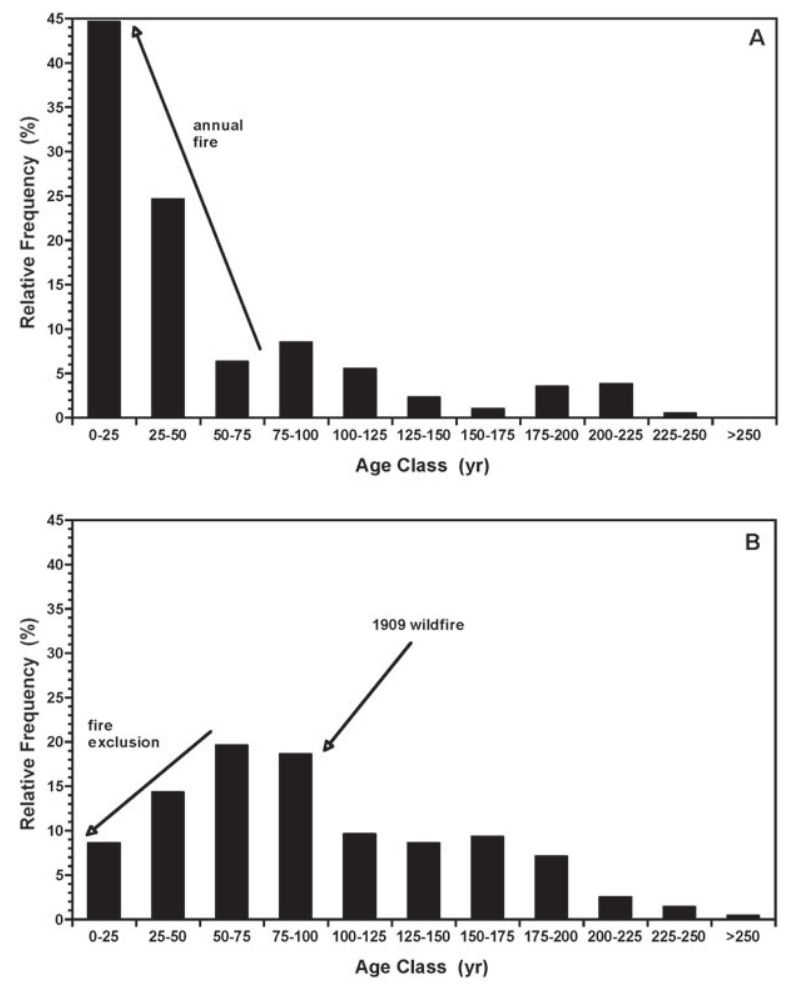

Fig. 6. Age-class frequency distributions based on relative frequency (\%) within each of 25 -a age classes of Pinus palustris stems, for A. Wade Tract and B. Boyd Tract. high-density plots (i.e. plots with $>10$ stems) versus low-density plots (1-2 stems per plot). These were the plot classes that departed most from expectation in the Poisson analysis (Table 1). Stems of P. palustris were generally smaller in high-density plots, with ca. $75 \%$ of stems in these plots being $<30 \mathrm{~cm}$ diameter at breast height (DBH). In contrast, $>80 \%$ of $P$. palustris stems in the low-density plots were $>30 \mathrm{~cm} \mathrm{DBH} \mathrm{(Fig.} \mathrm{7).}$

\section{Ground cover comparisons}

The ground cover differed markedly between the two sites. Species richness of the ground cover at the Wade Tract was $>4$ times that at the Boyd Tract (Table $2)$. Mean richness ( $\pm 1 \mathrm{SE}$ ) for all plots at the Wade and Boyd Tracts were $121 \pm 9$ and $28 \pm 10$ species per 1000 $\mathrm{m}^{2}$, respectively. In addition, herbaceous species were abundant in the ground cover of the Wade Tract plots, but were virtually absent at the Boyd Tract. Species dominance of ground cover was mixed at both sites, but more species shared dominance at the Wade than Boyd Tract. For example, between four and seven species on the Wade Tract and between two and four species on the Boyd Tract had $>10 \%$ cover in the plots. All plots on the Wade Tract contained abundant warm-season $\left(\mathrm{C}_{4}\right)$ grasses (e.g. Aristida beyrichiana, Sorghastrum secundum, Schizachyrium scoparium, S. tenerum, Ctenium aromaticum, Saccharum giganteum; see Table 2). By contrast, none of the plots on the Boyd Tract contained abundant grasses, and only one plot even contained a grass at all (Aristida stricta). All plots in both sites contained abundant shrub-size plants. These included both sprouts of trees (e.g. Quercus laevis, $Q$. incana, $Q$. margarettiae, $Q$. velutina, Carya alba, Cornus florida, Nyssa sylvatica) and ground cover shrubs (e.g., Quercus pumila, Ilex glabra, Gaylussacia dumosa, G. frondosa).

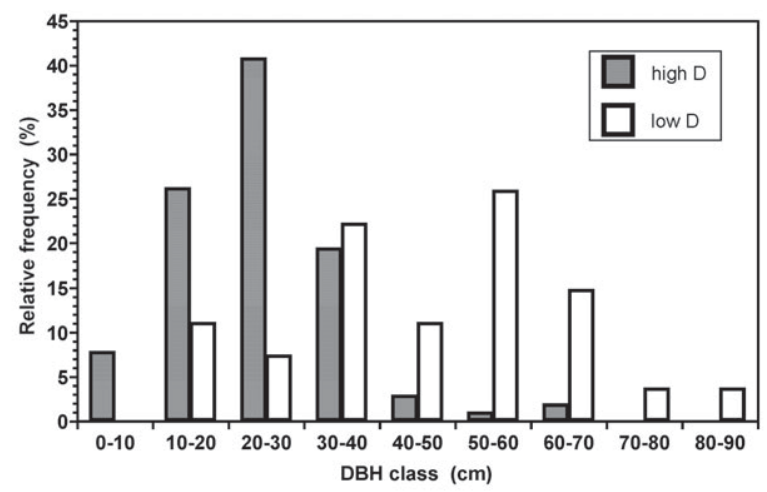

Fig. 7. Size-class frequency distributions, based on relative frequency (\%) within each of $10-\mathrm{cm}$ size classes of Pinus palustris stems for plots with $>10$ stems per plot (high D) and plots with 1-2 stems per plot (low D). 


\section{Application of the disturbance-driven phenomenolo- gical model to two old-growth Pinus palustris stands}

Disturbance regimes contrast sharply between the Wade and Boyd Tracts. The Wade Tract has experienced primarily biennial fires since record keeping at the site was initiated. By contrast, following its purchase by James Boyd circa 1900, the Boyd Tract experienced chronic fire exclusion. Nonetheless, there was a large, widespread wildfire in 1909 in the area surrounding Southern Pines, North Carolina, and this fire burned the Boyd Tract (Gilliam et al. 1993). Some effects of this fire can be seen in the relative age-class distribution of $P$. palustris, with a nearly two-fold increase in relative frequency of stems in the 100-125 a class to the 75-100 a class, suggesting post-fire regeneration of $P$. palustris (Fig. 6b). The fire-exclusion policy mandated by the Boyd family continued after this fire through the time that overstorey data were collected.

The two sites differ in the frequency of tropical storms. Storm tracks recorded by the National Oceanographic and Atmospheric Administration (see Gilliam $\&$ Platt 2006 for further description) are more numerous per decade in the Georgia coastal plain region containing the Wade Tract than in the North Carolina Sandhills region containing the Boyd Tract (http://www.aoml. noaa.gov/hrd/hurdat/DataByYearand Storm.htm). Thus, whereas the Wade Tract represents old-growth $P$. palustris in the presence of frequent fire and wind disturbances, the Boyd Tract exemplifies old-growth $P$. palustris with much lower frequencies of both disturbance types. Consequently, we interpret site-based differences in stand physiognomy in relation to differences in both disturbance regimes.

One of the more important predictions of our phenomenological model is the maintenance of discreet patches in the physiognomy of $P$.palustris stands. These patches include open patches devoid of pine overstorey and dominated by dense ground cover, as well as patches of $P$. palustris stems of a variety of sizes. Frequent fire both causes and responds to this high degree of spatial heterogeneity. Furthermore, although susceptibility of $P$. palustris seedlings to mortality from fire is initially high (Grace \& Platt 1995a), once P.palustris juveniles emerge as transient species from the ground cover their principle cause of mortality is catastrophic wind damage, such as that associated with tropical storms. Mortality during a single tropical storm, although typically low (Doren et al. 1993; Platt ety al. 2000; Batista \& Platt 2003), can be substantial in some stands (Boucher et al. 1991).

Comparisons of stand physiognomy - including basal area, density, and dispersion patterns of $P$. palustris stems - between the Wade and Boyd Tracts support
Table 1. Poisson test for dispersion pattern of Pinus palustris at the Boyd Tract, NC. Column 1 contains categories based on numbers of $P$. palustris stems per plot, whereas Column 2 contains the number of plots $(O)$ with the corresponding number of stems. The third column contains the expected number of plots $(E)$ with the corresponding number of stems based on the Poisson distribution (Zar 1996). Note that this test requires each category to have an $E$ of $>5 \%$ of the total number of plots (i.e. $E$ must be $>3$ ). Thus, $O$ - and $E$-data are pooled for the first three and last three categories.

\begin{tabular}{|c|c|c|c|}
\hline $\begin{array}{l}\text { Category } \\
\text { stems/ plot }\end{array}$ & $\begin{array}{l}\text { Observed number } \\
\text { of plots with } x\end{array}$ & $\begin{array}{l}\text { Expected number } \\
\text { of plots with } x\end{array}$ & \\
\hline$(x)$ & stems $(\mathrm{O})$ & stems (E) & $(\mathrm{O}-\mathrm{E})^{2} / \mathrm{E}$ \\
\hline 0 & 5 & 0.5 & \\
\hline 1 & $12\} 23$ & $2.4\} 8.7$ & 23.5 \\
\hline 2 & 6 & $5.8^{J}$ & \\
\hline 3 & 9 & 9.2 & 0 \\
\hline 4 & 6 & 11 & 2.3 \\
\hline 5 & 3 & 10.5 & 5.3 \\
\hline 6 & 6 & 8.3 & 0.6 \\
\hline 7 & 1 & 5.7 & 3.8 \\
\hline 8 & 4 & 3.4 & \\
\hline 9 & $2\} \quad 12$ & $1.8\} 5.7$ & 7.0 \\
\hline$>10$ & $6^{\prime}$ & $0.5^{\jmath}$ & \\
\hline Total & 60 & 59.1 & $\chi^{2}=42.5$ \\
\hline
\end{tabular}

these predictions. Basal area and density of all stems at the Wade Tract was overwhelmingly dominated by $P$. palustris, whereas only about one-half of the total basal area and $<10 \%$ of stem density at the Boyd Tract was $P$. palustris. However, although absolute densities of $P$. palustris were similar between sites, absolute basal area at the Boyd Tract was over twice that at the Wade Tract (Fig. 6a, b). This suggests that frequent fire and tropical storms at the Wade Tract has maintained high densities of $P$. palustris, particularly in the smaller regeneration classes. By contrast, fire exclusion at the Boyd Tract has inhibited $P$. palustris regeneration; the absence of tropical storms has allowed already present $P$. palustris stems to survive and grow to large sizes.

Although lacking a spatial component, comparison of ground cover composition is consistent with predictions of our model, primarily that fires exert their most direct influence on processes in the ground cover. High fire frequencies at the Wade Tract have selected for ground cover characteristics typical of old-growth pine savannas - high cover and species diversity, with the predominance of $\mathrm{C}_{4}$ grasses and numerous juveniles of $P$. palustris. Chronic fire exclusion at the Boyd Tract, on the other hand, has selected for the predominance of seedlings/sprouts of hardwood species that share dominance with $P$. palustris in the overstorey (Table 2). In the absence of differences in canopy and disturbance regimes, we would have expected the Boyd Tract to have ground cover species richness at the $1000-\mathrm{m}^{2}$ scale much 
Table 2. Mean CVS cover classes (Peet et al. 1998) for ground cover species for sites within the Wade Tract, GA, and the Boyd Tract, NC. Data shown are species with cover $\geq 1 \%$ in the plot (see Methods). $S$ indicates species richness for the entire plot.

\begin{tabular}{|c|c|c|c|c|c|}
\hline $\begin{array}{l}\text { A. Wade Tract } \\
\text { Upland }(S=104) \\
\text { Species }\end{array}$ & Class & $\begin{array}{l}\text { Mid-slope }(S=126) \\
\text { Species }\end{array}$ & Class & $\begin{array}{l}\text { Lowland }(S=133) \\
\text { Species }\end{array}$ & Class \\
\hline Aristida beyrichiana & 8 & Pinus palustris & 7 & Ctenium aromaticum & 6 \\
\hline Quercus incana & 6 & Quercus pumila & 7 & Ilex glabra & 6 \\
\hline Quercus laevis & 6 & Schizachyrium scoparium & 7 & Pityopsis graminifolia & 6 \\
\hline Quercus margarettiae & 6 & Sorghastrum secundum & 6 & Saccharum giganteum & 6 \\
\hline Sorghastrum secundum & 6 & Ageratina aromatica & 4 & Andropogon virginicus & 5 \\
\hline Tephrosia virginiana & 6 & Chrysopsis mariana & 4 & Chaptalia tomentosa & 5 \\
\hline Dichanthelium angustifolium & 5 & Dyschoriste oblongifolia & 4 & Eupatorium leucolepis & 5 \\
\hline Rhus copallinum & 5 & Eupatorium album & 4 & Helianthus angustifolius & 5 \\
\hline Ageratina aromatica & 4 & Morella pumila & 4 & Panicum verrucosum & 5 \\
\hline Clitoria mariana & 4 & Rhus copallinum & 4 & Saccharum coarctatum & 5 \\
\hline Dichanthelium ovale & 4 & Tephrosia virginiana & 4 & Schizachyrium scoparium & 5 \\
\hline Dyschoriste oblongifolia & 4 & Vaccinium darrowii & 4 & Aristida purpurascens & 4 \\
\hline Pteridium aquilinum & 4 & Desmodium ciliare & 3 & Dyschoriste oblongifolia & 4 \\
\hline Salvia azurea & 4 & Desmodium lineatum & 3 & Hibiscus aculeatus & 4 \\
\hline Schizachyrium scoparium & 4 & Dichanthelium ovale & 3 & Panicum anceps & 4 \\
\hline Sericocarpus tortifolius & 4 & Elephantopus elatus & 3 & Quercus pumila & 4 \\
\hline Andropogon gyrans & 3 & Gaylussacia nana & 3 & Rhexia alifanus & 4 \\
\hline Andropogon ternarius & 3 & Helianthus radula & 3 & Solidago stricta & 4 \\
\hline Desmodium strictum & 3 & Lespedeza angustifolia & 3 & Sorghastrum nutans & 4 \\
\hline Gaylussacia dumosa & 3 & Muhlenbergia capillaris & 3 & Andropogon glomeratus & 3 \\
\hline Gaylussacia nana & 3 & Quercus margarettiae & 3 & Carphephorus paniculatus & 3 \\
\hline Muhlenbergia capillaris & 3 & Sorghastrum nutans & 3 & Diodia virginiana & 3 \\
\hline Smilax glauca & 3 & Symphyotrichum adnatum & 3 & Diospyros virginiana & 3 \\
\hline Symphyotrichum concolor & 3 & & & Elionurus tripsacoides & 3 \\
\hline \multirow[t]{5}{*}{ Vernonia angustifolia } & 3 & & & Erigeron vernus & 3 \\
\hline & & & & Euthamia tenuifolia & 3 \\
\hline & & & & Hyptis alata & 3 \\
\hline & & & & Paspalum praecox & 3 \\
\hline & & & & Rhynchospora debilis & 3 \\
\hline
\end{tabular}

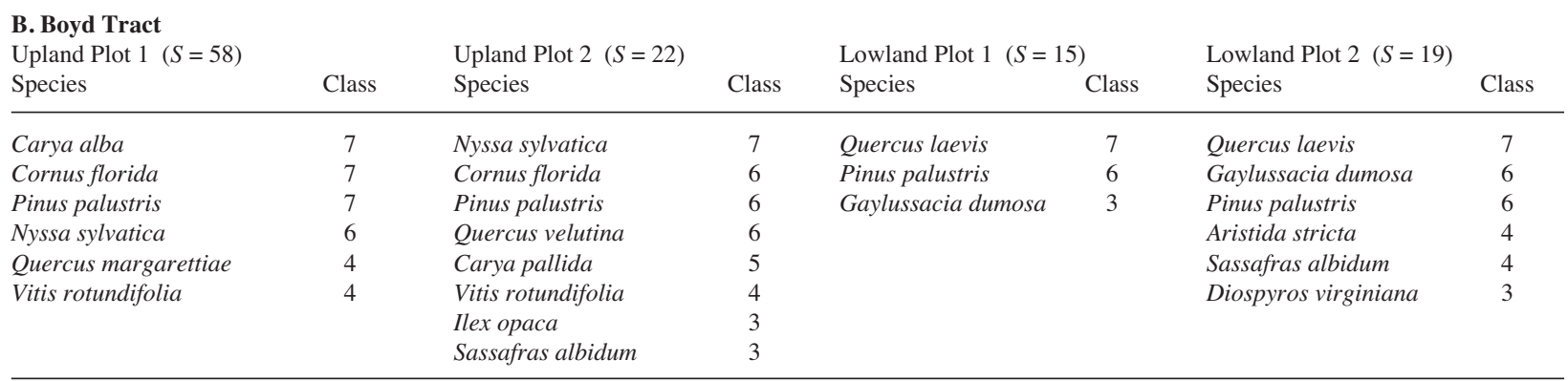

closer to that of the Wade Tract than was measured. Ground cover species richness in upland Pinus palustris savannas is generally highly correlated with soil silt content (Peet 2006), and both the Boyd and Wade tracts have soils with measurable levels of silt.

As already mentioned, the central feature of our model is its prediction of a high degree of spatial heterogeneity (patchiness) that is created and maintained in pine savannas by frequent natural disturbance. A wide range of ages and sizes of trees are represented in the mapped stand on the Wade Tract (Fig. 6a; see Platt et al. 1988, Platt \& Rathbun
1993; Noel et al. 1998). The pine stand consists of aggregations that are greatest for small-sized trees just leaving the ground cover. Over time, as trees grow and thin, the aggregation decreases until the background density of large-sized, old trees is essentially random. Open patches without trees comprise about $1 / 3$ of the stand area, and another $1 / 3$ of the open area contains small trees still in height growth (Noel et al. 1998).

In contrast, $P$. palustris at the Boyd Tract displays primarily a regular, or uniform, distribution (Table 1). Further comparisons, however, indicate that this is re- 
lated more to the spatial distribution of large, old pine than small, young ones. The fact that these young pines are actually quite patchy in distribution is consistent with the predictions of the model. We suggest that the vast majority of these pines represent the post-burn regeneration cohort following the wildfire of 1909. As predicted by the model, regeneration following the fire occurred in patches, which can be seen in the high frequencies of stems 77-100 a old (Fig. 6b) and 20-30 $\mathrm{cm}$ DBH (Fig. 7). Once again, the effect of fire exclusion is seen in decreased frequencies of stems in younger and smaller classes (Figs. 6 and 7).

Examination of Pinus palustris found in low-density plots (i.e. 1-2 stems per plot) reveals the nature of the size distributions of pines that are uniformly dispersed at the Boyd Tract (Fig. 7). These are generally much larger than pines found in patches. In addition, peaks in both the 30-40 and 50-60 cm DBH classes suggest that they may be of mixed cohorts. Certainly, these patterns indicate that, in the absence of fire, the degree of patchiness in the physiognomy of $P$. palustris declines.

Differences between sites in frequency distributions are most pronounced in classes $\leq 100$ a. For the Boyd Tract, this period followed the wildfire of 1909 (see Gilliam et al. 1993). It is during this time that the Tract was owned by James Boyd, who actively excluded fire at the site, a practice that drastically reduced Pinus palustris regeneration. During this same time, the Wade Tract was burned on a 1-2 a interval, promoting successful establishment and growth of $P$. palustris juveniles.

The sharp contrasts in ground cover composition between these old-growth Pinus palustris stands most likely have arisen from differences in fire regimes. Chronic absence of fire at the Boyd Tract has allowed establishment of seedlings/sprouts of woody species to exclude the dense and diverse herbaceous layer typical of $P$. palustris ecosystems (Gilliam et al. 1993). By contrast, the long-term, frequent-fire regime at the Wade Tract has promoted the dominance of species adapted to high fire frequencies, particularly the $\mathrm{C}_{4}$ grasses (Platt 1999).

During the past century, hurricanes have occurred at higher frequency along the Gulf coastal plain than they have along the Atlantic coastal plain (Simpson \& Lawrence 1971). During this period hurricanes of low intensity have had an average occurrence in the area surrounding the Wade Tract of once every one to two decades (Batista \& Platt 1997; Platt 1999). Even though such hurricanes typically result in low rates of mortality in old-growth pine stands, because of the susceptibility of large trees to wind damage it is likely that these storms maintain lower basal area and density than in areas experiencing lower hurricane frequencies (Platt \& Rathbun 1993; Platt et al. 2000; Batista \& Platt 2003). The result is a stand with numerous open patches (Platt
\& Rathbun 1993; Noel et al. 1998). These open patches, which may or may not contain downed trees, interact with fires to generate different types of openings that potentially influence recruitment of new pines into stands. Thus, stands that experience frequent hurricanes, like the Wade Tract, are predicted to be more uneven in age and size than stands experiencing less frequent hurricanes, even if fires occur frequently.

Periodic hurricanes constitute an unpredictable, but important source of mortality of overstorey pines. For example, in a single night Hurricane Kate (sustained winds about $160 \mathrm{~km} / \mathrm{h}$ ) caused direct mortality of large trees on the Wade Tract (located about $80 \mathrm{~km}$ from the Gulf of Mexico) equivalent to seven non-hurricane years of mortality from lightning and windthrows (Platt et al. 1988; Platt \& Rathbun 1993). Damage from hurricanes also is associated with extended mortality over several years after the hurricane (Platt et al. 2002). On the Wade Tract, direct mortality plus extended mortality (ca. 5\% of the population) was roughly equivalent to $15-20 \mathrm{a}$ of normal mortality of large trees in the stand (W.J. Platt, unpub. data). Such direct and extended mortality of large trees can enhance the open nature of southeastern pine savannas near the coast (Platt et al. 2002).

Stand-structural characteristics of the Wade Tract stand appear close to the historic condition. This stand is characterized by physiognomy and patch structure more appropriate as a reference condition for restoration of altered $P$. palustris ecosystems than the structural characteristics of the fire-suppressed Boyd Tract. Nonetheless, differences in composition of the two stands do not only reflect differences in fire suppression. We propose that the higher density of large trees at the Boyd Tract reflects a lower frequency of tropical storms of sufficient intensity to reduce the basal area and density of larger trees. Thus, although the dynamic processes influenced by natural disturbances are similar in the two stands, differences in frequency of both tropical storms and fire appear to have had strong effects on the stand structure in these two old-growth stands.

\section{Conclusions}

Pinus palustris stands are characterized by a deceptive structural simplicity involving an often monospecific overstorey underlain by a species-rich ground cover. Indeed, heterogeneity in $P$. palustris ecosystems occurs primarily in a horizontal, rather than vertical dimension. Further, the physiognomy changes frequently over time, as a result of the patch dynamics of the pine stand. Nonetheless, intrinsic and extrinsic ecological processes generate substantial variation in this apparent simple physiognomy. The model we develop in this paper 
underscores the diversity and complexity of mechanisms important in producing variations on this simple physiognomy. These mechanisms potentially operate in all stands and involve natural disturbances of fire and tropical storms.

Both disturbance regimes have been influenced by humans. Fire regimes have been altered for more than a century, and all current $P$. palustris stands are approaching a condition where few trees are present that entered the stand under pre-settlement fire regimes. Hurricane intensity (and thus frequency of major hurricanes) has been increasing as well (Knutson \& Tuleya 2004; Emmanuel 2005). Thus, at least in coastal pine savannas, mortality rates of older trees have been increased, and over the coming decades those trees recruited under more natural disturbance regimes are likely to disappear from pine savannas. The continued development of stand models like the one we propose here is critical for conservation of pine savannas, if some semblance of a savanna-like habitat is to persist, given effects of other predicted environmental changes (e.g., Saxon et al. 2005). Further, practical application of model concepts to restoration and management of pine savannas is needed if any are to remain that resemble those that occurred prior to alterations of disturbance regimes. We propose that such application is essential for maintenance of the high biodiversity, both of plants and animals, in pine savannas.

Acknowledgements. Numerous people and institutions have assisted with the long-term studies on the Boyd and Wade Tracts. Sampling and analysis at the Boyd Tract was aided by Mac Goodwin, Becky Amos, Brad Yurish, Tracy Hippensteel, Nicole Turrill Welch, and many individuals on staff at the Weymouth Woods-Sandhills Nature Preserve. The mapped plot and data from the Wade Tract used in this paper resulted primarily from the field work of S. Rathbun and G. Evans. Additional vegetation samples were obtained courtesy of the Carolina Vegetation Survey (see Peet et al. 1998; Earley 2003). Support for the study came from Tall Timbers Research Station and the National Science Foundation (DEB 8012090, BSR 8718803, W.J.P., P.I.). Many people have contributed in various ways to the ideas that have appeared in other papers, but are assembled in the conceptual model developed as part of this study: through Tall Timbers Research Station: Mary Davis, Greg Evans, Jeff Glitzenstein, Sharon Hermann, Maynard Hiss, Larry Landers, Bruce Means, Margaret Platt, Steve Rathbun, Kevin Robertson and Donna Streng; through Everglades National Park: Brian Beckage, Jim DeCoster, Lisu Derungs, Bob Doren, Jed Redwine, Harry Slater, \& Matt Slocum; through LSU: Will Batista, Steve Brewer, Susan Carr, Paul Drewa, Tom Doyle, Sue Grace, Kyle Harms, Jean Huffman, Charles Kwit, Barry Moser, Jill Noel, Matt Olson, Heather Passmore, Jarrod Thaxton and Carrie Yoder; through the Carolina Vegetation Survey: Richard Duncan, Eric Kjelmark, Michael Schafale, Alan Weakley, Tom Wentworth.

\section{References}

Anon. 2006. The PLANTS Database, version 4.0. 6 March 2006 (http://plants.usda.gov). Data compiled from various sources by Mark W. Skinner. National Plant Data Center, USDA, NRCS, Baton Rouge, LA, US.

Batista, W.B.\& Platt, W.J. 1997. An old-growth definition for southern mixed hardwood forests. United States Department of Agriculture Forest Service, Southern Research Station General Technical Report SRS-10, Asheville, NC, US.

Batista, W.B. \& Platt, W.J. 2003. Tree population response to hurricane disturbance: syndromes in a southeastern United States old-growth forest. J. Ecol. 91: 197-212.

Beckage, B., Platt, W.J., Slocum, M.G. \& Panko, R. 2003. Influence of the El Niño-Southern Oscillation on fire regimes in the Florida Everglades. Ecology 84: 31243130 .

Boucher, D.H., Vandermeer, J.H., Yih, K. \& Zamora, N. 1991. Contrasting hurricane damage in tropical rain forest and pine forest. Ecology 71: 2022-2024.

Brockway, D.G. \& Outcalt, K.W. 1998. Gap-phase regeneration in longleaf pine wire grass ecosystems. Forest Ecol. Manage. 106: 125-139.

Conner, W.H., Day, Jr., J.W., Baumann, R.H. \& Randall, J.M. 1989. Influence of hurricanes on coastal ecosystems along the northern Gulf of Mexico. Wetl. Ecol. Manage. 1: 4556.

Doren, R.F., Platt, W.J. \& Whiteaker, L.D. 1993. Density and size structure of slash pine stands in the everglades region of south Florida. Forest Ecol. Manage. 59: 295-311.

Drewa, P.B., Platt, W.J. \& Moser, E.B. 2002. Fire effects on resprouting of shrubs in headwaters of southeastern longleaf pine savannas. Ecology 83: 755-767.

Drewa, P.B., Thaxton, J.M. \& Platt, W.J. 2006. Responses of root-crown shrubs to differences in longleaf pine savanna fire regimes: exploring old-growth questions in secondgrowth systems. Appl. Veg. Sci. 9: 27-36.

Earley, L. 2003. Boot camp for botanists. Endeavors 2003(3). http://research.unc.edu/endeavors

Emmanuel, K. 2005. Increasing destructiveness of tropical cyclones over the past 30 years. Nature 436: 686-688.

Frost, C.C. 1993. Four centuries of changing landscape patterns in the longleaf pine ecosystem. Proc. Tall Timbers Fire Ecology Conference 18: 17-44.

Frost, C.C. 1998. Presettlement fire frequency regimes of the United States: a first approximation. Proc. Tall Timbers Fire Ecology Conference 20: 70-81.

Gilliam, F.S. 1991. Ecosystem-level significance of acid forest soils. In: Wright, R.J., Baligar, V.C. \& Murrmann, R.P. (eds.) Plant-soil interactions at low pH, pp. 187-195. Kluwer, Dordrecht, NL.

Gilliam, F.S. \& Platt, W.J. 1999. Effects of long-term fire exclusion on tree species composition and stand structure in an old-growth longleaf pine forest. Plant Ecol. 140: 1526.

Gilliam, F.S. \& Platt, W.J. 2006. Conservation and restoration of the Pinus palustris ecosystem. Appl. Veg. Sci. 9: 5-10.

Gilliam, F.S. \& Roberts, M.R. 2003a. Introduction: concep- 
tual framework for studies of the herbaceous layer. In: Gilliam, F.S. \& Roberts, M.R. (eds.) The herbaceous layer in forests of Eastern North America, Ch. 1, pp. 3-11. Oxford University Press, New York, NY, US.

Gilliam, F.S. \& Roberts, M.R. 2003b. The dynamic nature of the herbaceous layer: synthesis and future directions for research. In: Gilliam, F.S. \& Roberts, M.R. (eds.) The herbaceous layer in forests of Eastern North America, Ch. 14, pp. 323-337. Oxford University Press, New York, NY, US.

Gilliam F.S., Yurish, B.M. \& Goodwin, L.M. 1993. Community composition of an old-growth longleaf pine forest: relationship to soil texture on tree species. Bull. Torrey Bot. Club 120: 287-294.

Glitzenstein, J.S., Platt, W.J. \& Streng, D.R. 1995. Effects of fire regime and habitat on tree dynamics in north Florida longleaf pine savannas. Ecol. Monogr. 65: 441-476.

Grace, S.L. \& Platt, W.J. 1995a. Effects of adult tree density and fire on the demography of pre-grass stage juvenile longleaf pine (Pinus palustris Mill.). J. Ecol. 95: 75-86.

Grace, S.L. \& Platt, W.J. 1995b. Neighborhood effects on juveniles in an old-growth stand of longleaf pine (Pinus palustris Mill.). Oikos 72: 99-105.

Grace, S.L., Hamrick, J.L. \& Platt, W.J. 2004. Estimation of seed dispersal in an old-growth population of longleaf pine (Pinus palustris) using maternity exclusion analysis. Castanea 69: 207-215.

Gresham, C.A., Williams, T.M. \& Lipscomb, D.J. 1991. Hurricane Hugo wind damage to southeastern U.S. coastal forest tree species. Biotropica 23: 420-426.

Harcombe, P.A., Glitzenstein, J.S., Knox, R.G., Orzell, S.L. \& Bridges, E.L. 1993. Vegetation of the longleaf pine region of the west Gulf coastal plain. Proc. Tall Timbers Fire Ecology Conference 18: 83-104.

Hermann, S.M. 1993. The longleaf pine ecosystem: ecology, restoration and management. Proc. Tall Timbers Fire Ecology Conference 18: 265-274.

Hodanish, S., Sharp, D., Collins, W., Paxton, C. \& Orville, R.E. 1997. A ten year monthly lightning climatology of Florida: 1986-1995. Weather Forecasting 12: 427-446.

Knutson, T.R. \& Tuleya, R.E. 2004. Impact of $\mathrm{CO}_{2}$-induced warming on simulated hurricane intensity and precipitation: sensitivity to the choice of climate model and convective parameterization. J. Climate 17: 3478-3495.

Landers, L.L. 1991. Disturbance influences on pine traits in the southeastern United States. Proc. Tall Timbers Fire Ecology Conference 17: 61-98.

McCarthy, B.C. 2003. The herbaceous layer of eastern oldgrowth deciduous forests. In: Gilliam, F.S. \& Roberts, M.R. (eds.) The herbaceous layer in forests of Eastern North America, Ch. 6, pp. 163-176. Oxford University Press, New York, NY, US.

McGuire, J.P., Mitchell, R.J., Moser, E.B., Pecot, S.D., Gjerstad, D.H. \& Hedman, C.W. 2001. Gaps in a gappy forest: plant resources, longleaf pine regeneration, and understory response to tree removal in longleaf pine savannas. Can. J. For. Res. 31: 765-778.

Moore, M.M., Covington, W.W.\& Fulé, P.Z. 1999. Reference conditions and ecological restoration: a southwestern ponderosa pine perspective. Ecol. Appl. 9: 1266-1277.

Noel, J.M., Platt, W.J. \& Moser, E.B. 1998. Structural characteristics of old- and second-growth stands of longleaf pine (Pinus palustris) in the Gulf coastal region of the U.S.A. Conserv. Biol. 12: 533-548.

Noss, R.F., Beier, P., Covington, W.W., Grumbine, R.E., Lindenmayer, D.B., Prather, J.W., Schmiegelow, F., Sisk, T.D. \& Vosick, D.J. 2006. Recommendations for integrating restoration ecology and conservation biology in ponderosa pine forests of the southwestern United States. Restor. Ecol. 14: 4-10.

Olson, M.S. \& Platt, W.J. 1995. Effects of habitat and growing season fires on resprouting of shrubs in longleaf pine savannas. Vegetatio 119: 101-118.

Palik, B.J., Mitchell, R.J., Houseal, G. \& Pederson, N. 1997. Effects of canopy structure on resource availability and seedling response in a longleaf pine ecosystem. Can. J. For. Res. 27: 1458-1464.

Peet, R.K. 2006. Ecological classification of longleaf pine woodlands. In: Shibu, J., Jokela, E.J. \& Miller, D.L. (eds). The longleaf pine ecosystem: ecology, silviculture and restoration. Springer-Verlag, New York, NY, US.

Peet, R.K. \& Allard, D.J. 1993. Longleaf pine vegetation of the southern Atlantic and eastern Gulf coast regions: a preliminary classification. Proc. Tall Timbers Fire Ecology Conference 18: 45-81.

Peet, R.K., Wentworth, T.R. \& White, P.S. 1998. A flexible, multipurpose method for recording vegetation composition and structure. Castanea 63: 262-274.

Platt, W.J. 1999. Southeastern pine savannas. In: Anderson, R.C., Fralish, J.S.\& Baskin, J. (eds.) The savanna, barren, and rock outcrop communities of North America, pp. 2351. Cambridge University Press, Cambridge, UK.

Platt, W.J. \& Rathbun, S.L. 1993. Dynamics of an old-growth longleaf pine population. Proc. Tall Timbers Fire Ecology Conference 18: 275-297.

Platt, W.J. \& Schwartz, M.W. 1990. Temperate hardwood forests. In: Myers, R. \& Ewel, J. (eds.) Ecosystems of Florida, pp. 194-229. University of Central Florida Press, Orlando, FL, US.

Platt, W.J., Evans, G.W.\& Rathbun, S.C. 1988. The population dynamics of a long-lived conifer (Pinus palustris). Am. Nat. 131: 491-525.

Platt, W.J., Glitzenstein, J.S. \& Streng, D.R. 1991. Evaluating pyrogenicity and its effects on vegetation in longleaf pine savannas. Proc. Tall Timbers Fire Ecology Conference 17: 143-161.

Platt, W.J., Doren, R.F. \& Armentano, T.V. 2000. Effects of Hurricane Andrew on stands of slash pine (Pinus elliottii var. dens $a$ ) in the everglades region of south Florida. Plant Ecol. 146: 43-60.

Platt, W.J., Beckage, B., Doren, R.F. \& Slater, H.H. 2002. Interactions of large-scale disturbances: prior fire regimes and hurricane mortality of savanna pines. Ecology 83: 1566-1572.

Platt, W.J., Carr, S.M., Reilly, M. \& Fahr, J. 2006. Influences of pine savanna overstorey on ground cover biodiversity. Appl. Veg. Sci. 9: 37-50.

Platt, W.J., Huffman, J.M., Slocum, M.G. \& Beckage, B. In 
press. Fire regimes and trees in Florida dry prairie landscapes. In: Noss, R. \& Singh, S. (eds.) Land of fire and water: The Florida dry prairie ecosystem. Avon Park Air Force Range and Department of Defense, Avon Park, FL, US.

Quigley, M.F. \& Platt, W.J. 2003. Composition and structure of seasonally deciduous forests in the Americas. Ecol. Monogr. 73: 87-106.

Rebertus, A.J., Williamson, G.B. \& Platt, W.J. 1993. Impacts of temporal variation in fire regime on savanna oaks and pines. Proc. Tall Timbers Fire Ecology Conference 18: 215-225.

Saxon, E., Baker, B., Hargrove, W., Hoffman, F. \& Zganjar, C. 2005. Mapping environments at risk under different global climate change scenarios. Ecol. Lett. 8: 53-60.

Schwartz, M.W. 1994. Natural distribution and abundance of forest species and communities in northern Florida. Ecology 75: 687-705.

Schwarz, G.F. 1907. The Longleaf pine in Virgin Forest: a silvical study. John Wiley \& Sons, New York, NY, US.

Simpson, R.H. \& Lawrence, M.B. 1971. Atlantic hurricane frequencies along the U.S. coastline. National Oceanic and Atmospheric Administration Technical Memo NWS SR-58, Asheville, NC, US.

Slocum, M.G., Platt, W.J. \& Cooley, H.C. 2003. Effects of differences in prescribed fire regimes on patchiness and intensity of fires in subtropical savannas of Everglades National Park, Florida. Restor. Ecol. 11: 91-102.
Stone, G.W. \& Finkl, C.W. (eds.) 1995. Impacts of Hurricane Andrew on the coastal zones of Florida and Louisiana: 2226 August, 1992. J. Coastal Res. 21: 1-364.

Streng, D. R., Glitzenstein, J.S. \& Platt, W.J. 1993. Evaluating season of burn in longleaf pine forests: a critical literature review and some results from an ongoing long-term study. Proc. Tall Timbers Fire Ecology Conference 18: 227-263.

Thaxton, J.M. 2003. Effects of fire intensity on ground cover shrubs in a frequently burned longleaf pine savanna. Ph.D. Thesis, Louisiana State University, Baton Rouge, LA, US.

Thaxton, J.M. \& Platt, W.J. In press. Effects of small-scale variation in fuels on fire intensity in a frequently burned longleaf pine savanna. Ecology.

Wahlenberg, W.G. 1946. Longleaf pine: its use, ecology, regeneration, protection, growth and management. Charles Lathrop Pack Forestry Foundation, Washington, DC, US.

Walker, J.W. \& Peet, R.K.. 1984. Composition and species diversity of pine - wiregrass savannas of the Green Swamp, North Carolina. Vegetatio 55: 163-179.

Walker, L.R., Lodge, D.J., Brokaw, N.V.L. \& Waide, R.B. (eds.) 1991. Ecosystem, plant, and animal responses to hurricanes in the Caribbean. Biotropica 23: 313-515.

Williamson, G.B. \& Black, E.M. 1981. High temperature of forest fires under pines as a selective advantage over oaks. Nature 293: 643-644.

Zar, J.H. 1996. Biostatistical analysis, 3rd. ed. Prentice Hall, Upper Saddle River, NJ, US.

Received 28 July 2004;

Accepted 11 April 2006.

Co-ordinating Editor: P.S. White. 